\title{
NARRATIVES OF A SENSE OF BELONGING: PERSPECTIVES FROM A SAMPLE OF INTERNATIONAL STUDENTS IN SOUTH AFRICA
}

\author{
W. T. Chinyamurindi \\ Department of Business Management \\ University of Fort Hare \\ Alice, South Africa \\ e-mail: chinyaz@gmail.com
}

\section{ABSTRACT}

South African universities have witnessed an increase in the number of international student enrolment. Strategies need to be put into place into ways of integrating and helping students develop a sense of belonging. The aim of this research (using a narrative analysis) is to understand how international students develop a sense of belonging as part of their enrolment at a rural university in the Eastern Cape Province of South Africa. In achieving this, a focus group discussion and reflective diaries were used at the start and end of the 2015 academic year using 20 international students. Data was analysed using the three levels of meaning making adopted in previous qualitative research. Three findings in the form of narratives emerge based on the data analysis. First, the formation of an in and out group mentality amongst international students. Second, the study reveals the factors that were narrated as influencing student's sense of belonging. Despite all this, students still narrated as "suffering a sense of elsewhere". Based on the findings and narratives generated from this work, suggestions are made that affect the work of lecturers, university administrators and also policy makers on what can be done to assist international students in developing a sense of belonging within a South African context as part of their enrolment.

Keywords: international students, narratives, sense of belonging, perceptions, experiences

\section{INTRODUCTION}

South Africa is witnessing a growth in the number of enrolments from international students. The backdrop of this is within a global context that is witnessing mobility especially amongst students (Hegedorn and Zhang 2012). South Africa is witnessing a growth in international student enrollment (HEMIS 2014). Most notably, the growth appears to be students from the South African Development Community (SADC) region. Figures in 2010 showed students from SADC standing at 46204 and those students outside SADC to be 19 915. It is argued that South Africa needs this enrolment from international students, as this provides much needed intellectual capital to the country (Smith and Khawaja 2011).

Given the critical role that international students play in host countries, university 
administrators and academics should continually prioritise an understanding of their "academic success, health and psychological well-being” (Chirkov et al. 2007, 200). A challenge that international students face concerns issues of coping with their new setting or issues around acculturation (Smith and Khawaja 2011). Traditionally, acculturation has been defined as "those phenomena which result when groups of individuals with different cultures come into continuous first-hand contact, with subsequent changes in the original culture patterns of either or both groups” (Redfield, Linton and Herskovits 1936, 149).

Thus, as argued in this article, any experience that affects the acculturation process of international students can be thought of as creating a distance. This distance can affect not just a sense of identity but also the mental health, life satisfaction and psychological wellbeing of international students (Ward 1996; Ward and Searle 1991). A further categorization of factors affecting international students has been proposed to be issues of language, practical stressors, educational, socio-cultural and discriminatory issues faced by international students (Smith and Khawaja 2011). From an improvement point of view, an understanding of matters that affect international students as part of their enrolment can be useful in the provision of high-quality service (Nzivo and Chuanfu 2013). Others like Shao and Scherlen (2011) cite the need for such efforts as an obligation by higher education administrators and academics in viewing international students as valuable customers in how they operate.

Some gaps exist in the literature, especially when working with international students as a sample cohort. Further, Liu and Winn (2009) note issues around academic literacies of international students and how they adjust in their new setup as a fundamental aspect that deserves further empirical attention. Others (e.g. Sin 2015) note the dearth of studies that explore how international students use information in their everyday life in coping with challenges they may face. The argument here could be that some studies using international students as sample cohort adopt a positivist philosophy hinging on quantitative empirical investigations (e.g. Brunton and Jeffrey 2011; Sin 2015; Zhang and Goodson 2011). To advance existing knowledge on international students' behaviour, interpretivism as a philosophy and the qualitative paradigm can be beneficial. Given (2016) argues for the qualitative approach as useful in understanding better thoughts, processes, meanings and experiences of subjects holistically. There has been a notable shift in research in international education amongst academics and students to incorporate the qualitative approach (e.g. Sawir et al. 2008; Trice 2003; Townsend and Poh 2008). 


\section{LITERATURE REVIEW}

\section{Sense of belonging and the academic context}

Studying a sense of belonging within a higher education context is gaining currency (e.g. Kolesovs and Melne 2017). This is actuated by the complex challenges that characterise higher education. On one end is the need for institutions of higher learning that strive on improving the academic performance of students (Mansour, Bahman and Hadis 2011). Conversely, is the need for creating an environment in which students not only thrive but also operate at their optimum (Mohammad 2010). All this places importance on the need to develop a sense of belonging, also given the overall ramification towards an individual's sense of meaning (Lambert, Stillman and Hicks 2013). This research narrowed its focus to studying a sense of belonging from the context of international students within an academic context. Yao (2016) makes an argument that such a study is needed as it can be a pre-cursor to interventions for academic and social integration.

\section{Sense of a belonging: The academic context and international students}

Studying outside your home country has been described to be a "life changing venture" and associated with "hardship and struggle” for the student (Forbush and Foucault-Welles 2016, 1). This could be that such an experience not only demands total commitment but also entails the need to constantly re-adjust to changes as they are presented. Yao (2016) notes that more studies that pay attention to how international students adjust in their host country and how this affects their framing of a sense of belonging are needed. This sense of belonging is defined in the literature as feelings of international students and how they not only identify but also affiliate with the university community around them (Hausmann et al. 2009; Strayhorn 2012). Notably, there is an acknowledgement of studies that focus on a sense of belonging within an academic community to pay attention mostly to the lived experiences of local students (Museus and Maramba 2011), with international students being an under-represented cohort (Yao 2016).

Emphasis is placed on understanding how a sense of belonging develops, given its link to how students potentially develop an affiliation and acceptance to the community around them (Yao 2016). Others argue that a sense of belonging amongst students may potentially be linked to a student's persistence and academic success (Hausmann et al. 2009). Given that there is theorising around the role of a sense of belonging, especially amongst under-represented population groups (Strayhorn 2012), a study of this nature would be of relevant to the international students given their minority status on campus. The next section details are based 
on the empirical literature issues that may potentially affect international students' experience on campus and, subsequently, their sense of belonging.

This article defines any aspect that affects international student experience and sense of estrangement to be distance. Other authors prefer to refer this distance to be in the form of stressors (Smith and Khawaja 2011). Calls exist for more empirical work in various contexts that explores how international students deal with stressors around them (Smith and Khawaja 2011). This article argues that stressors create a distance that affects the lived experiences of international students. Forbush and Foucault-Welles (2016) viewed this distance to enact stress mostly in the social and academic adaptation of the international student. This also places emphasis on understanding how information seeking behaviours can also be critical in how this distance can be managed (Sin and Kim 2013).

Some studies (e.g. Ishimura and Bartlett 2014) cite the role of libraries in addressing challenges that may affect international students. The emphasis here is on addressing the issue that concerns academic challenges especially those faced by international students. This emanates from the idea that international students come from an educational background in their home country that could be different from that of the host country (Amsberry 2010). Thus, the way to addressing academic distance that can exist is through information and knowledge portals such as university libraries. Others (e.g. Jackson and Sullivan 2011) argue for the role of the international office as an essential resource where international students can get support to assist them to adjust to the changes around them. In other studies (e.g. Ang and Liamputtong 2008), international students were found to under-utilise campus activities such as visiting campus counselling services. Research using a sample of Asian students studying in Australia (Khawaja and Dempsey 2008), has found maladaptive coping behaviours in the form of denial, substance abuse, self-blame, venting and behavioural disengagement to be used in coping with distance.

Research exists (especially amongst immigrants) detailing the role and influence of language in assisting or hindering a sense of belonging (Martinez-Callaghan and Gill-Lacruz 2017). The issue of language appears to emerge due to the cultural differences that may be existent especially within a campus setting (Yao 2016). In some cases, language then is found to exist as a barrier between international and domestic students that stops them from interacting (e.g. Li, Chen and Duanmu 2010; McMahon 2011; Yao 2016).

By addressing issues that affect the adaptation of international students in host countries, this can help develop a sense of community that affects local and international students (Brunton and Jeffrey 2014). Further, it may result in the development of a sense of belonging 
(Krause, Hartley and McInnis 2005) and better academic performance (Rientes et al. 2012). The need to belong has been identified as a key driver and human need (Maslow 1987). Further, the need to belong has been deemed key within an academic context as it significantly affects the life of a student (Guan, Tregonning and Keenan 2008; Krause et al. 2005; Tinto 1975; 1993). Amongst international students, Tatar (2005) argues for a sense of belonging to not only be important but also has been found to be a determinant that affects how these students participate in classroom activity. In this case, the desire to be part of the group is placed as more important than the level of participation in an academic environment (Tompson and Tompson 1996). Brunton and Jeffrey (2014) have found a sense of belonging to be influencing learner empowerment and argue for more empirical work to unpack this, especially amongst international students. The aim of this study was to investigate how international students perceive and experience the notion of a sense of belonging as part of their enrolment at a rural university in the Eastern Cape of the province of South Africa. Specifically, the following research question is set: a) what issues do international students perceive and experience as affecting their sense of belonging as part of their enrolment?

\section{METHODOLOGY}

A qualitative methodology was adopted in aiming to investigate how international students perceive and experience the notion of a sense of belonging as part of their enrolment at a rural university in the Eastern Cape of province of South Africa, In achieving this, a narrative approach grounded in social constructionism was used to explore the experiences of international students as part of their enrolment in South Africa. The use of narratives is gaining currency within higher education research in South Africa (Chinyamurindi 2016a; 2016b) and also in studying international students as a research sample internationally (Wang, Andre and Greenwood 2015). Narratives offer an opportunity to understand the emerging sense-making that accompanies individual experience be it positive or negative (Chinyamurindi 2012). Further, narratives allow for the researcher to maximise an understanding of those experiences for the individual (Loftus and Higgs 2010) and can offer an opportunity to possibly explain such experiences (Binder and Kotsopoulos 2013).

This study's participants were recruited through an invite being posted at the International Office of the participating university. Potential participants had to leave their email address through a designated official from the office. Data was collected at two points. First (at the start of the 2015 academic year), 20 international students were invited to take part in a research project at the beginning of the academic year through a focus group session and an ongoing 
research diary project after that. The purpose here was for international students to narrate perceptions and experiences around: a) issues that foster a sense of community and b) issues that hinder a sense of community particularly within the campus setting. Table 1 provides a descriptive description of the 20 participants.

Table 1: Participants to the study

\begin{tabular}{|c|c|c|c|}
\hline Pseudonym & Country of Origin & Course of Study & Salient Information \\
\hline Able & Zimbabwean & $\begin{array}{l}\text { Business } \\
\text { Management }\end{array}$ & $\begin{array}{l}\text { Male, } 23 \text { years old and actively involved in } \\
\text { sports on campus. }\end{array}$ \\
\hline Brandon & Kenyan & Agriculture & Male, 24 years old and student leader. \\
\hline Carmelle & Nigerian & Economics & $\begin{array}{l}23 \text { year old female who takes prides in being } \\
\text { an Igbo. }\end{array}$ \\
\hline Doreen & Zimbabwean & Public Administration & $\begin{array}{l}23 \text { year old female who described herself as } \\
\text { a "hard worker" and "game-changer". }\end{array}$ \\
\hline Everton & Malawian & Industrial Psychology & 25 year old male and tutor on campus. \\
\hline Farai & Zimbabwean & Social Sciences & $\begin{array}{l}26 \text { year old male and student leader on } \\
\text { campus. }\end{array}$ \\
\hline Gladys & Ghanaian & Accounting & $\begin{array}{l}24 \text { year old female active with a campus } \\
\text { religious group. }\end{array}$ \\
\hline Handee & Cameroon & Social Sciences & $\begin{array}{l}25 \text { year old female interested in } \\
\text { humanitarian work. }\end{array}$ \\
\hline Innocent & Zimbabwean & Chemistry & $\begin{array}{l}23 \text { year old male who described himself as } \\
\text { "the campus guy". }\end{array}$ \\
\hline Jimalo & Zimbabwean & Botany & $\begin{array}{l}27 \text { year old male interested in a career in } \\
\text { academia. }\end{array}$ \\
\hline Kuana & Ugandan & Education & $\begin{array}{l}25 \text { year old female who is a firm believer in } \\
\text { the power of education. }\end{array}$ \\
\hline Loveness & Zimbabwean & Accounting & $\begin{array}{l}24 \text { year old female student leader on } \\
\text { campus. }\end{array}$ \\
\hline Malvin & Nigerian & Botany & 26 year old male tutor on campus. \\
\hline Noble & Zimbabwean & Geography & $\begin{array}{l}23 \text { year old male and student parliament } \\
\text { member }\end{array}$ \\
\hline Omega & Nigerian & Agriculture & 26 year old female and tutor on campus \\
\hline Prudence & Zimbabwean & Communication & $\begin{array}{l}25 \text { year old female who does community } \\
\text { work. }\end{array}$ \\
\hline Koffi & Ghanaian & $\begin{array}{l}\text { Business } \\
\text { Management }\end{array}$ & 24 year old male and tutor on campus. \\
\hline Uche & Nigerian & Agriculture & 26 year old male and active social blogger. \\
\hline Melody & Zimbabwean & $\begin{array}{l}\text { Business } \\
\text { Management }\end{array}$ & 26 year old female and tutor. \\
\hline Wesley & Kenyan & Statistics & 25 year old male and tutor on campus. \\
\hline
\end{tabular}

The focus group session was used to generate a discussion within a group setting about issues that affect international students and their sense of belonging. Following the focus group session, reflective diaries were handed over to the international students and collected monthly for the purpose of transcription and data analysis. Second (at the end of the academic year), a final focus group session was conducted to collect the final data. In this final session, international students shared experiences and stories that either fostered or hindered their sense of community, particularly within the campus setting (in addition to the diary entries). The two research techniques (focus groups and the reflective diaries) were deemed key in allowing 
interviewees to be open in sharing their stories and the accompanying reflection based on their perceptions and experiences of being international students (Meho 2006).

The data from the focus groups and reflective diaries at point 1 and 2 of the data collection were exported into QSR International's NVivo 9, a data analysis and management software package useful when dealing with a lot of text, graphic, audio and video data (Reuben and Bobat 2014). A data analysis procedure based on three levels of meaning making, as adopted in previous narrative research in South Africa (e.g. Chinyamurindi 2012; 2016a; 2016b) and internationally (McCormack 2000), was used.

Steps were taken to ensure methodological rigour and data integrity. First, ethical clearance was sought and granted by the participating institution. Second, all participants taking part in the study through the focus group interviews and reflective diary entries had to give informed consent before participating in the research. Third, using the recommendation of methodological rigour (Tobin and Begley 2004), some steps were taken for the purpose of maintaining data trustworthiness (credibility, transferability, dependability and confirmability).

\section{FINDINGS}

The aim of this study was to investigate how international students perceive and experience the notion of a sense of belonging as part of their enrolment at a rural university in the Eastern Cape of Province of South Africa. The results of the research are three-fold. First, international students viewed themselves as part of an in-group that was separate from an out-group (mostly non-international students). As a result, constant reference was made to "them” and "us" concerning these two groups. This often resulted in situations of labelling and stereotyping. Such a situation affected international students' sense of belonging. Second, international students cited factors affecting their belonging as: a) the need for curricular that fosters international examples; b) more visibility and involvement of the international office and c) governments such as the Department of Home Affairs to be seen as interested in their affairs. Finally, participants narrated that despite individual and university efforts, they still suffered from a "sense of elsewhere" - a psychological alienation of the present characterised by an intense longing for home. This was accompanied by a desire of artefacts such as food, music and need to be with a community from their home countries. These findings are discussed next.

\section{Narrative One: "Us" and "Them"}

The first salient narrative common in the focus group discussions and reflective diary entries was international students seeing themselves as a distinct group of the local students. Thus, 
activities around campus were even categorised within these in-group and out-group classifications. Table 2 details how the researcher arrived at this narrative but also illustrates quotes showing the rationale of this grouping amongst the sample of international students that took part in this study.

Table 2: "Us" and "Them" Framing

\begin{tabular}{|l|l|l|}
\hline Meaning of narrative & Initial codes & Illustrating quotes \\
\hline $\begin{array}{l}\text { The "us" and "them" for some } \\
\text { appears to be framed by } \\
\text { happenings within the country (e.g. } \\
\text { xenophobic attacks) and the } \\
\text { ensuing sense-making thereafter. }\end{array}$ & $\begin{array}{l}\text { Us foreigners } \\
\text { The locals }\end{array}$ & $\begin{array}{l}\text { "After the xenophobic attacks, my } \\
\text { attitudes towards the locals } \\
\text { changed. I just felt although we } \\
\text { were humans, there were more } \\
\text { important than us internationals. As } \\
\text { a result, could do nothing." }\end{array}$ \\
\hline $\begin{array}{l}\text { A further categorisation of the "us" } \\
\text { and "them" appears to be enforced } \\
\text { by artefacts deemed to be distinct } \\
\text { between international and local } \\
\text { students. }\end{array}$ & $\begin{array}{l}\text { International students dress } \\
\text { International students talk }\end{array}$ & $\begin{array}{l}\text { "We differently speak and walk } \\
\text { students. That can make us easily } \\
\text { stand out from a distance to the } \\
\text { locals." }\end{array}$ \\
\hline $\begin{array}{l}\text { This framing of the "us" and "them" } \\
\text { is driven by stereotyping that } \\
\text { happens on campus. International } \\
\text { students are viewed as rich. }\end{array}$ & $\begin{array}{l}\text { Perception being rich } \\
\text { International students have it all }\end{array}$ & $\begin{array}{l}\text { "I was once a victim of a mugging, I } \\
\text { really think I was mugged because } \\
\text { I am an international student and } \\
\text { perception that we are rich and } \\
\text { have it easier than the locals." }\end{array}$ \\
\hline
\end{tabular}

Given the framing of the "us" and "them", international students would feel pressurised, at times having no alternative but seeking to only hang out with those who are similar to them due to the status of being foreign. Interestingly, the participants cited an awareness of the rich diversity that can exist amongst themselves, but this appears as a common thread that wove their experience with the status of being international. This is aptly summarised by one participant, Farai:

"You see even on campus, we as international students are different, I sometimes think that some of our local students don't realise that. Importantly, for as long as our student's cards say international, we stand together ... something like unity in diversity”.

\section{The source of "Us" and "Them"}

Related to the first narrative, "us" and "them", a sense of belonging appears to emerge for international students through group identification. However, the experience of this sense of belonging appears to be affected by a range of issues on campus that thwart this belonging. The source of the grouping was mainly attributed to two issues by the international students. First, international students flagged the influence of the xenophobic attacks that saw attacks on foreign nationals as causing them to group with others due to the affiliation of being a foreigner. Omega from Nigeria put it this way: 
"I am from Nigeria, and when I saw the images of the xenophobic attacks, something inside me just changed. I had an intense dislike of this country, South Africa. Don't get me wrong, it's a nice place, but I realised it could be a dangerous place to be a foreigner. So from that day, I decided to be closer to my brothers and sisters, not necessarily from Nigeria but from anywhere than South Africa."

Another participant Melody attributed the source of the grouping to be deliberate on campus was driven by the closeness that international students share in them being international. To this she also commented:

"There is glue that brings us, international students, together - our similarity in leaving our home countries and coming to a foreign country. We find ourselves attracted to each other by this happening. See some international students hanging out together; you will just notice this.”

This leads to the second narrative finding of this research illustrating those issues that affect the sense of belonging

\section{Narrative Two: Challenges around a sense of belonging}

International students cited factors affecting their belonging as a) curriculum transformation; b) more visibility and involvement of the international office and c) a desire for government departments such as the Department of Home Affairs to be seen as interested in the affairs of international students. These factors are presented next.

\section{Curriculum transformation}

A challenge noted as affecting a sense of belonging amongst international students was a curriculum as taught in the university that needed transformation. International students felt the curriculum as taught did not integrate global knowledge with emphasis more on dialogues specific to the African continent. Given this perception, international students felt detached from their lived reality. Some narrations are provided to illustrate this. Able from Zimbabwe narrated this:

"You know, I accept the fact that I am in South Africa and all but really, I think more needs to be done to bring more African stories in the classroom. You attend some classes, and the lecturer stands there and at least to me appears oblivious to African case examples in teaching. Undoubtedly, it just makes us as international students feel not part of the teaching that happens. Sadly, it has happened in more than one subject.”

Interestingly, as in the first narrative finding, the "us" and "them" appears to emerge in the 
second narrative. For instance, one participant (Brandon) cited the need for a curricular that also incorporates "the international experience":

"In some of our classes, you just hear of local examples. One time, a lecturer started talking about Twizza, and I understand we are in their country, but there also appears to be no attempt to have international examples. I raised my hand and cited the case of Tusker, popular in East and West Africa. I am sad to say this, but the lecturer did not even know what I was talking about. The local students also looked mesmerised. I guess that's how I feel about Twizza."

\section{Visibility and involvement of the international office}

Other discussions were around the visibility and role of the international office and how it relates to the issues of a sense of belonging. International students that participated in this study appear to applaud the international office for its efforts in assisting the international students. One participant described this office and its mandate as an "oasis of hope in a dry and barren land". Further, another participant described the office as key in "attempting to bring a flavour of home on the campus”. Although these were positive views that existed around the role of the international office, some participants cited some concerns around the functioning of this office, especially in fostering a sense of belonging for international students. One participant succinctly put it:

"The biggest room in the house is the room for improvement. A want an international office that not only organises accommodation for us when we have campus disruptions. I want an international office that makes me feel at home while being away from home.”

Through further probing, participants were asked to give with practical examples how the international office can assist as part of their enrolment. Some activities were identified, and this can be useful in understanding how international students frame the meaning and experience of a sense of belonging. One participant cited the need for intercultural activities: "some form of celebration of the diversity on campus to me can be helpful in making me feel that I belong.” Another participant cited the need for public debates on campus: "I think xenophobia was allowed to happen in society due to a lack critique and analysis of those things that make us African, so it's regrettable when such platforms are created in a space that is supposed to allow for debate and critique, the campus setting.” Finally, one participant narrated their expectation of the international office.

"The international office needs to understand they exist not just for the international students but also for the local students. So far the focus has been to assist us but priority should also be on assisting our local students also integrate with us. When both local and international students feel 
they belong, our campus will be a nice place not only to study but also stay.”

Finally, within the second narrative as a finding, participants seemed to cite stressors that emerge from issues that concern their legal status. In essence, issues around their legal status in the country are constant reminders of their foreign status; as put by one participant, "they do not belong”. This sentiment is expressed by the views of one international student:

"I literally get sick when I have to do anything with Home Affairs. Last year I waited an entire year for an application of my study permit to be proved. You know that feeling when you know something is not right and you literally tread with caution. I just felt I don't belong in the country just because of some of the delays in Home Affairs issues.”

International students that took part in this study cited the need for a new way of operating at the Department of Home Affairs, one that is more than just a compliance also to help make their stay in the country comfortable. One participant narrated a harrowing experience of being picked up by the police because he did not have a passport.

"I had gone shopping in the nearby town, my permit had expired, and I had been waiting for Home Affairs to hear my appeal. So while I was waiting, I had no valid visa. I got caught by the police and arrested for being an illegal immigrant. I had to be assisted after spending a night in jail by the International Office. I just knew that this country was not doing much to integrate international students.”

A final narrative to emerge from this study was what one participant described as a "sense of elsewhere" - defined as a psychological alienation of the present characterised by an intense longing for home. This is presented next.

\section{Narrative Three: Suffering a "sense of elsewhere"}

One of the greatest challenges manifest within the lived experiences of international students concerned was seeking to balance between making best of the present while in South Africa while having an intense longing for home. One participant even equated this feeling as "trying to empty the Indian Ocean with a teaspoon”. The issue appears to be a sense of helplessness when international students fail to control things happening back at home as part of their enrolment. One participant described this:

"My father had been sick for a long time. I hated hearing my phone ring or the notification you get when you receive a new message. My life in South Africa was lived with a fear of what was 
happening to my father back in Nigeria. The inevitable then happened. I was in a class, and I remember just walking out and cried. I cried - yes for my father but also for my helpless state.”

An interesting inquiry was to try and understand how exactly students dealt with this "sense of elsewhere”. International students cited the role and the desire of having artefacts around them such as food, music and needed to be within a community of those from their home countries. This was aptly put by one participant from Zimbabwe:

"Put some Oliver Mtukudzi, a nice hot plate of sadza [traditional meal] and some people from home, and that does the magic for me. I live for each reunion with my country mates. Such encounters are more than just about the food, music and company. These events are a reminder that we are sojourners here in South Africa, one day we will go back home. Before then the food, music and company are a waymark on the journey home.”

\section{DISCUSSION}

The aim of this study was to investigate how international students perceive and experience the notion of a sense of belonging as part of their enrolment at a rural university in the Eastern Cape of Province of South Africa. Specifically, the following research question is set: a) what issues do international students perceive and experience as affecting their sense of belonging as part of their enrolment? The study pays credence to issues that affect how international students adjust to the new setting they are located in, and this has been identified to be key to assisting international students (Smith and Khawaja 2011). To international students, the issues identified in this study are argued to influence not just their lived experience but also their sense of belonging (Ward 1996). The study also confirms previous research that attests to the "hardship and struggle" that characterise the experience of international students (Forbush and Foucault-Welles 2016, 1). This study placed emphasis also on perceived institutional failures within and outside the university as part of these hardships. This study suggested practical ways students adjust to their experience of being international and subsequently the framing of a sense of belonging. Notably, unlike in previous studies, this study positions international students in this study as never arriving at a sense of belonging but finding ways to manage the daily realities around them. A contribution of this study was to advance understanding around how a sense of belonging develops amongst international students cited as a needed empirical agenda (Yao 2016) also given that international students remain an under-represented group (Strayhorn 2012). A qualitative research approach relying on the narrative inquiry was helpful in understanding better "thoughts, processes, meanings and experiences” of international student experience holistically (Given 2016). This extends the empirical research that exists where the qualitative approach is suggested to assist in understanding issues that affect 
international students (Sawir et al. 2008; Trice 2003; Townsend and Poh 2008).

Based on previous work using the same methodological approach (e.g. Chinyamurindi 2016a; 2016b) qualitative nature of this work usually relies on small sample sizes and do not assume a position of generalizability. This can be flagged as a methodological concern. However, some limitations exist in the current work. First, a bias existed in how the sample of participating international students was selected. Only those international students most available to take part in the focus group were included in the sample. Second, given participant voice to the role of the university, especially the international office, the views of such office structures (important as they are) are not in included in the study. Albeit these limitations, the aim of this work was to understand the emerging sense-making (Chinyamurindi 2016a; 2016b) around the experience of being international students and the issues of how a sense of belonging is not only perceived but also experienced. To this end, this research has attempted to do so.

Some recommendations can be made for practice based on the findings of this research. First, there is a notable concern around the issues raised in the first narrative around the grouping done by international students. In a healthy campus scenario, such behaviour of only associating with those whom you only identify with, as social classifications, can be thought to be two-way. First, as a dysfunctional behaviour where international students may not want to interact with other groups and only those they perceive to belong with. However and secondly, it could be a self-preservation tactic of feeling safe and achieving a sense of belonging. Regardless of the two positions, university authority needs to constantly study these two tactics and offer any assistance for the local and international students. Thus, there is need to come up with strategies that make both international and local students aware of the mutual benefit of associations between the groups. This can be done through campus-wide activities that heighten awareness and attention to the value of diversity and collaborative interactions amongst local and international students. Thus, information dissemination can be key in achieving all this not just for international students but also their local counterparts (Sin 2015). Second, based on the findings of this research, there is a need for more visibility of the international office as an important hub, not just for international but also local students. It could be that through just framing the operations of such an office to be the sole mandate of international students, this creates potential challenges for both local and international students. Campus fairs that appeal to both local and international students can serve as useful in challenging stereotypes that emanate for both groupings. Notably, there is also need to address issues that affect international students, particularly those that concern immigration. Participants to this study narrated great distress on issues that concern immigration and called for a revamp to the services, especially 
the turnaround of visa applications processed by the Department of Home Affairs. These suggestions can be thought of as key in the provision of good quality service and improving the well-being of international students (Nzivo and Chuanfu 2013), thus placing emphasis on the role of both administrators and academics in ensuring that this happens (Shao and Scherlen 2011).

Future research could also explore how a sense of belonging, as a comparative study, develops amongst local students. Future research could explore the element of rurality and how it links with the development of a sense of belonging. This may be an interesting basis for conceptualising issues of a sense of belonging in the South African higher education especially on rural campuses. Finally, given the issues explored through the qualitative and narrative approach used in this research, future research could adopt a quantitative and survey approach to ascertain determinants of a sense of belonging amongst international students with academic success and even life satisfaction. Such an investigation may help (using large sample sizes) them to benefit through a sense of belonging and outcomes that relate to international students' lived experience. Thus, the researcher also argues for the value of the quantitative approach used within research on international students (Brunton and Jeffrey 2011; Sin 2015; Zhang and Goodson 2011).

\section{CONCLUSION}

The study highlights the value of narratives in understanding the lived experiences of international students and the subsequent sense making that accompanies their enrolment, especially in the host country. Such an understanding, marred by difficulty and hardship, can be a useful precursor to interventions that assist the lived experiences and wellbeing of students away from home.

\section{REFERENCES}

Amsberry, D. 2010. Deconstructing plagiarism: International students and textual borrowing practices. Reference Librarian 51(1): 31-44.

Ang, P. L. D. and P. Liamputtong. 2008. "Out of the circle”: International students and the use of university counselling services. Australian Journal of Adult Learning 48: 108-130.

Binder and Kotsopoulos 2013. Multimodal literacy narratives: Weaving the threads of young children's identity through the arts. Journal of Research in Childhood Education 25(4): 339-363.

Brunton, M. and L. Jeffrey. 2014. Identifying factors that influence the learner empowerment of international students. International Journal of Intercultural Relations 43: 321-334.

Chinyamurindi, W. T. 2012. An investigation of career change using a narrative and story-telling inquiry. South African Journal of Human Resource Management 10(2): 1-11.

Chinyamurindi, W. T. 2016a. Using narrative analysis to understand factors influencing career choice amongst a sample of distance learning students in South Africa. South African Journal of 
Psychology 46(3): 390-400.

Chinyamurindi, W. T. 2016b. A narrative investigation into the meaning and experience of career success: Perspectives from women participants. South African Journal of Human Resource Management 14(1): 1-11.

Chirkov, V., M. Vansteenkiste, R. Tao and M. Lynch. 2007. The role of self-determined motivation and goals for study abroad in the adaptation of international students. International Journal of Intercultural Relations 31(2): 199-222.

Forbush, E. and B. Foucault-Welles. 2016. Social media use and adaptation among Chinese students beginning to study in the United States. International Journal of Intercultural Relations 50: 1-12.

Given, L. M. 2016. 100 Questions (and answers) about qualitative research. Thousand Oaks: Sage.

Guan, J., S. Tregonning and L. Keenan. 2008. Social interaction and participation: Formative evaluation of online CME modules. Journal of Continuing Education in the Health Professions 28(3): 172179.

Hausmann, P. R., L. R. Ye, J. W. Schofield and R. L. Woods. 2009. Sense of belonging and persistence in White and African-American first-year students. Research in Higher Education 50: 649-669.

Hegedorn, L. S. and L. Y. Zhang. 2012. The use of agents in recruiting Chinese undergraduates. http://www.usc.edu/programs/cerpp/docs/HagedornandZhang.pdf (Accessed 12 June 2016).

HEMIS. 2014. https://chet.org.za/data/sahe-open-data (accessed 5 June 2016).

Ishimura, Y. and J. C. Bartlett. 2014. Are librarians equipped to teach international students? A survey of current practices and recommendations for training. The Journal of Academic Librarianship 40: 313-321.

Jackson, P. and P. Sullivan. (Eds.). 2011. International students and academic libraries: Initiatives for success. Chicago, IL: Association of College and Research Libraries.

Khawaja, N. G and J. Dempsey. 2008. A comparison of international and domestic tertiary students in Australia. Australian Journal of Guidance and Counselling 18: 30-46.

Kolesovs, A. and I. Melne. 2017. Predictors of the sense of belonging to country: Exploring a new model. Proceedings of the International Scientific Conference, Volume 1, 26-27 May 2017.

Krause, K., R. J. Hartley and C. McInnis. 2005. The first year experience in Australian universities: Findings from a decade of national studies. Canberra: Australian Department of Education, Science and Training.

Lambert, N. M., T. F. Stillman and J. A. Hicks. 2013. To belong is to matter: Sense of belonging enhances meaning in life. Personality and Social Psychology Bulletin 39(11): 1418-1427.

Li, G., W. Chen and J. Duanmu. 2010. Determinants of international student's academic performances: A comparison between Chinese and other international students. Journal of Studies in International Education 14: 389-405.

Liu, G. and D. Winn. 2009. Chinese graduate students and the Canadian academic library: A user study at the University of Windsor. The Journal of Academic Librarianship 35(6): 565-573.

Loftus, S. and J. Higgs. 2010. Researching the individual in workplace research. Journal of Education \& Work 23(4): 377-388.

Martinez-Callaghan, J. and M. Gill-Lacruz. 2017. Developing identity, sense of belonging and social networks among Japanese immigrants in Scotland and Spain. Asian and Pacific Migration Journal 26(2): 241-261.

Maslow, A. H. 1987. Motivation and personality. $3^{\text {rd }}$ Edition. Boston, MA: Addison-Wesley.

Mansour, G., B. Bahman and E. Hadis. 2011. Factors affecting accounting students' performance: The case of students at the Islamic Azad University. International Conference on Education and Educational Psychology. Social and Behavioral Sciences 29: 122-128.

McCormack, C. 2000. From interview transcript to interpretative story: Part 1. Viewing the transcript through multiple lenses. Field Methods 12(4): 282-297. 
McMahon, P. 2011. Chinese voices: Chinese learners and their experiences of living and studying in the United Kingdom. Journal of Higher Education Policy and Management 33: 401-414.

Meho, L. I. 2006. E-mail interviewing in qualitative research: A methodological discussion. Journal of the American Society for Information Science and Technology 57(10): 1284-1295.

Mohammad, A. 2010. Relationship between self-esteem and academic achievement amongst preuniversity students. Journal of Applied Sciences 10(20): 2474-2477.

Museus, S. D. and D. C. Maramba. 2011. The impact of culture on Filipino student's sense of belonging. The Review of Higher Education 34(2): 231-258.

Nzivo, C. and C. Chuanfu. 2013. International students' perception of library services and information resources in Chinese academic libraries. The Journal of Academic Librarianship 39: 129-137.

Redfield, R., R. Linton and M. J. Herskovits. 1936. Memorandum for the study of acculturation. American Anthropologist 38(1): 149-152.

Reuben, S. and S. Bobat. 2014. Constructing racial hierarchies of skill - Experiencing affirmative action in a South African organisation: A qualitative review. South African Journal of Industrial Psychology 40(1): 1-12.

Rientes, B., S. Beausaert, T. Grohnert, S. Niemantsverdriet and P. Kommers. 2012. Understanding academic performance of international students: The role of ethnicity, academic and social integration. Higher Education 63(6): 685-700.

Shao, X. and A. Scherlen. 2011. Chinese academic libraries serving international students and scholars: An assessment of three case studies. The International Information \& Library Review 43(1): 5361.

Sawir, E., S. Marginson., A. Deumert., C. Nyland and G. Ramia. 2008. Loneliness and international students: An Australian study. Journal of Studies in International Education 12: 148-180.

Sin, S. C. J. 2015. Demographic differences in international students' information source uses and everyday information seeking challenges. The Journal of Academic Librarianship 41: 466-474.

Sin, S. C. J and K. S. Kim. 2013. International students' everyday life information seeking: The informational value of social networking sites. Library and Information Science Research 35(2): 107-11.

Smith, R. A. and N. G. Khawaja. 2011. A review of the acculturation experiences of international students. International Journal of Intercultural Relations 35(6): 699-713.

Strayhorn, T. L. 2012. College students' sense of belonging: A key to educational success for all students. New York, NY: Routledge.

Tatar, S. 2005. Classroom participation by international students: The case of Turkish graduate students. Journal of Studies in International Education 9(4): 337-355.

Tinto, V. 1975. Dropout from higher education: A theoretical synthesis of recent research. Review of Educational Research 45(1): 89-125.

Tinto, V. 1993. Leaving college: Rethinking the causes and cures of student attrition. $2^{\text {nd }}$ Edition. Chicago: University of Chicago Press.

Tobin, G. A. and C. M. Begley. 2004. Methodological rigor within a qualitative framework. Journal of Advanced Nursing 48(4): 388-396.

Tompson, H. B. and G. H. Tompson. 1996. Confronting diversity issues in the classroom with strategies to improve satisfaction and retention of international students. Journal of Education for Business 72(1): 53-57.

Townsend, P. and H. J. Poh. 2008. An exploratory study of international students studying and living in a regional area. Journal of Marketing for Higher Education 18: 240-263.

Trice, A. 2003. Faculty perceptions of graduate international students: The benefits and challenges. Journal of Studies in International Education 7: 379-403.

Wang, C., K. Andre and K. M. Greenwood. 2015. Chinese students studying at Australian universities 
with specific reference to nursing students: A narrative literature review. Nurse Education Today 35: 609-619.

Ward, C. 1996. Acculturation. In Handbook of intercultural training, ed. D. B. Landis and S. Rabi. Thousand Oaks, CA: Sage Publications, Inc.

Ward, C. and W. Searle. 1991. The impact of value discrepancies and cultural identity on psychological and sociocultural adjustment of sojourners. International Journal of Intercultural Relations 15(2): 209-224.

Yao, C. W. 2016. Unfulfilled expectations: Influence of Chinese international students' roommate relationships on sense of belonging. Journal of International Students 6(3): 762-778.

Zhang, J. and P. Goodson. 2011. Predictors of international students' psychosocial adjustment to life in the United States: A systematic review. International Journal of Intercultural Relations 35: 139162. 